Keywords: Gloveboxes,

Polymers, Gloves,

Characterization, Permeation,

Puncture Testing, Tensile

Testing, Thermogravimetric

Analysis, Dynamic Mechanical

Analysis

Retention: 25 yrs-10561

SRNL-STI-2012-00147

\title{
Glovebox Glove Characterization Summary
}

\author{
P.S. Korinko \\ Y. Breakiron
}

March 9, 2012

\section{We Put Science To Work}

The Savannah River National Laboratory is managed and operated for the U.S. Department of Energy by

SA VAN NAH RIVER N UCLEAR SOLUTIONS, LLC

AIKEN, SC USA 29808 • SRNL.DOE.GOV 


\section{SRNL-STI-2012-00147}

\section{Glovebox Glove Characterization Summary}

Approvals:

Signature on file

P. S. Korinko, Author

Materials Compatibility and Welding Technology

Signature on file

Y. Breakiron, Author

Tritium Engineering Intern, Clemson University

Signature on file

E. A. Clark, Technical Review

Materials Compatibility and Welding Technology

Signature on file

T. M. Adams, Manager

Materials Compatibility and Welding Technology
$4-9-2012$

$5-11-2012$

$5-14-2012$

5-14-2012 


\section{Table of Contents}

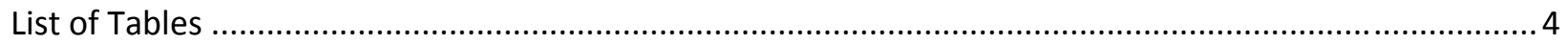

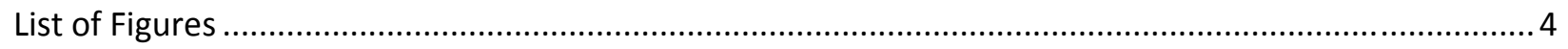

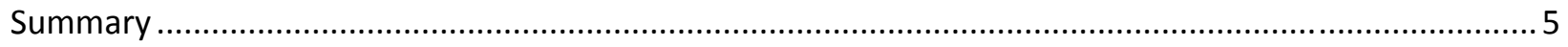

Background …

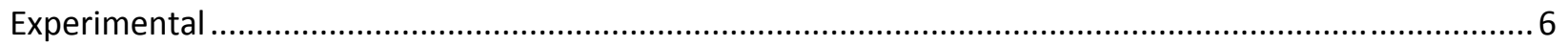

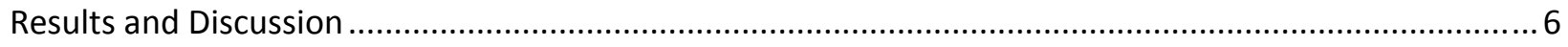

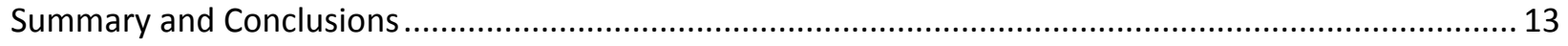

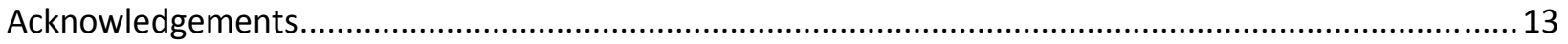

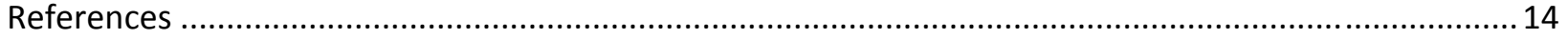

\section{List of Tables}

Table 1. Description of gloves and ID used for the testing.

Table 2. Average Hydrogen and Air Permeability. ........................................................................... 8

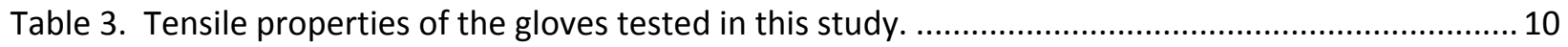

Table 4. Average measured Tg, Storage Modulus, and Tan $\delta$ for all the samples................................. 12

\section{List of Figures}

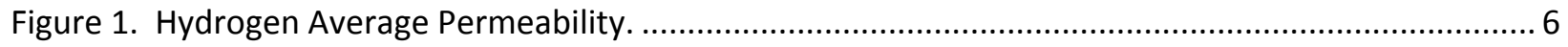

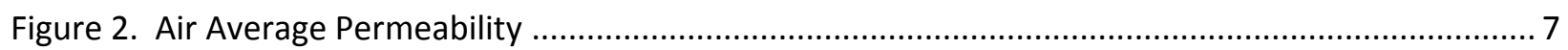

Figure 3. Graphical representation of tritium permeation in 24 hours for each glove type and thickness tested.

Figure 4. Specific mass change for glove samples exposed at $90^{\circ} \mathrm{C}$ to argon, J-27-BH is read on the right

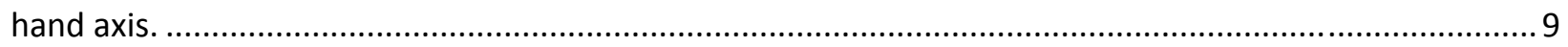

Figure 5. Puncture resistance of the gloves evaluated in this study. ..................................................... 10

Figure 6 . Tensile properties of gloves tested in this study. .............................................................. 11

Figure 7. Glass transition temperatures for the gloves tested in this study that exhibited single $T_{g} \ldots . . . . .12$ 


\section{SRNL-STI-2012-00147}

\section{Glovebox Glove Characterization Summary}

\section{Summary}

A task was undertaken to determine primarily the permeation behavior of various glove compounds from four manufacturers. As part of the basic characterization task, the opportunity to obtain additional mechanical and thermal properties presented itself. Consequently, a total of fifteen gloves were characterized for permeation, Thermogravimetric Analysis, Puncture Resistance, Tensile Properties and Dynamic Mechanical Analysis. Detailed reports were written for each characterization technique used. This report contains the summary of the results.

\section{Background}

Currently, butyl gloves are used in the facility because of their low permeability; however, butyl is not a particularly tough, puncture resistant, or abrasion resistant glove. To improve the physical and mechanical properties, the butyl gloves may be used with over-gloves when exposed to wear applications. The Tritium Facility and SRS glovebox subject matter expert has been working with several vendors to characterize and improve the glove properties. Four vendors: North, Piercan, Guardian and Jung, have supplied stock and experimental glove compositions and thicknesses for engineering evaluation. The gloves from these vendors, with the composition and nominal thickness listed in Table 1 , have been characterized for permeability in air and hydrogen (1) thermal decomposition using Thermogravimetric Analysis (2) Puncture Resistance (3) Tensile Properties (4) and Dynamic Mechanical Analysis (5). Details for each characterization can be found in the reference reports. This document is a brief summary of the findings of the various characterization techniques.

Table 1. Description of gloves and ID used for the testing.

\begin{tabular}{|c|c|c|c|c|c|c|c|}
\hline Vendor & Composition & $\begin{array}{l}\text { Thickness } \\
\text { (mils) }\end{array}$ & ID & Vendor & Composition & $\begin{array}{l}\text { Thickness } \\
\text { (mils) }\end{array}$ & ID \\
\hline North & Butyl & 15 & NB15 & North & Butyl & 30 & NB30 \\
\hline Piercan & Butyl & 15 & PB15 & Piercan & Butyl & 30 & PB30 \\
\hline Piercan & $\begin{array}{l}\text { Electrostatic } \\
\text { Discharge } \\
\text { Butyl }\end{array}$ & 15 & PESDB15 & Piercan & $\begin{array}{l}\text { Electrostatic } \\
\text { Discharge } \\
\text { Butyl }\end{array}$ & 24 & PESDB24 \\
\hline Guardian & Butyl & 15 & GB15 & Guardian & Butyl & 30 & GB30 \\
\hline Jung & $\begin{array}{l}\text { Butyl- } \\
\text { Hypalon }\end{array}$ & 27 & $\mathrm{JBH} 27$ & Jung & Butyl-Viton ${ }^{\oplus}$ & 20 & JBV20 \\
\hline Jung & Viton & 24 & JV24 & Jung & Viton ${ }^{\infty}$ & 31 & JV31 \\
\hline Piercan & Polyurethane & 15 & PU15 & Piercan & $\begin{array}{l}\text { Polyurethane- } \\
\text { Hypalon }\end{array}$ & 20 & PUY20 \\
\hline Piercan & Hypalon & 25 & PY25 & & & & \\
\hline
\end{tabular}




\section{Experimental}

The permeation testing was conducted on a purpose built apparatus in SRNL. Disk samples were cut from the glove sleeves and tested at subatmospheric pressures from 70 to 700 Torr at room temperature.

Thermogravimetric Analysis (TGA) was conducted using a TA Instruments TGA 951. Isothermal tests were run at 90,120 , and $150^{\circ} \mathrm{C}$ with argon purge gas for times up to 8 hours.

Puncture testing was conducted in agreement with ASTM D-120(6) using an Instron Model 4705 load frame including a MTS Systems Renew Package. Disks were cut from the hand portion of the glove.

Tensile testing was conducted on the same equipment as puncture testing and in agreement with ASTM D412(7) for tensile testing polymers. An extension rate of $20 \mathrm{in} / \mathrm{min}$ and a $200 \mathrm{lbf}$ load cell were used.

A TA Instruments 2950 Dynamic Mechanical Analyzer was used for this study. It is a forced oscillation, non-resonant, constant amplitude instrument. A tensile clamp, or sample holder was used due to the thickness of the sample and broad temperature range of interest. Rectangular test samples were cut from each glove. Tests in triplicate were completed from about $20^{\circ} \mathrm{C}$ below the glass transition temperature $\left(T_{\mathrm{g}}\right)$ to the maximum vendor recommended temperature or $150^{\circ} \mathrm{C}$, whichever temperature was lower.

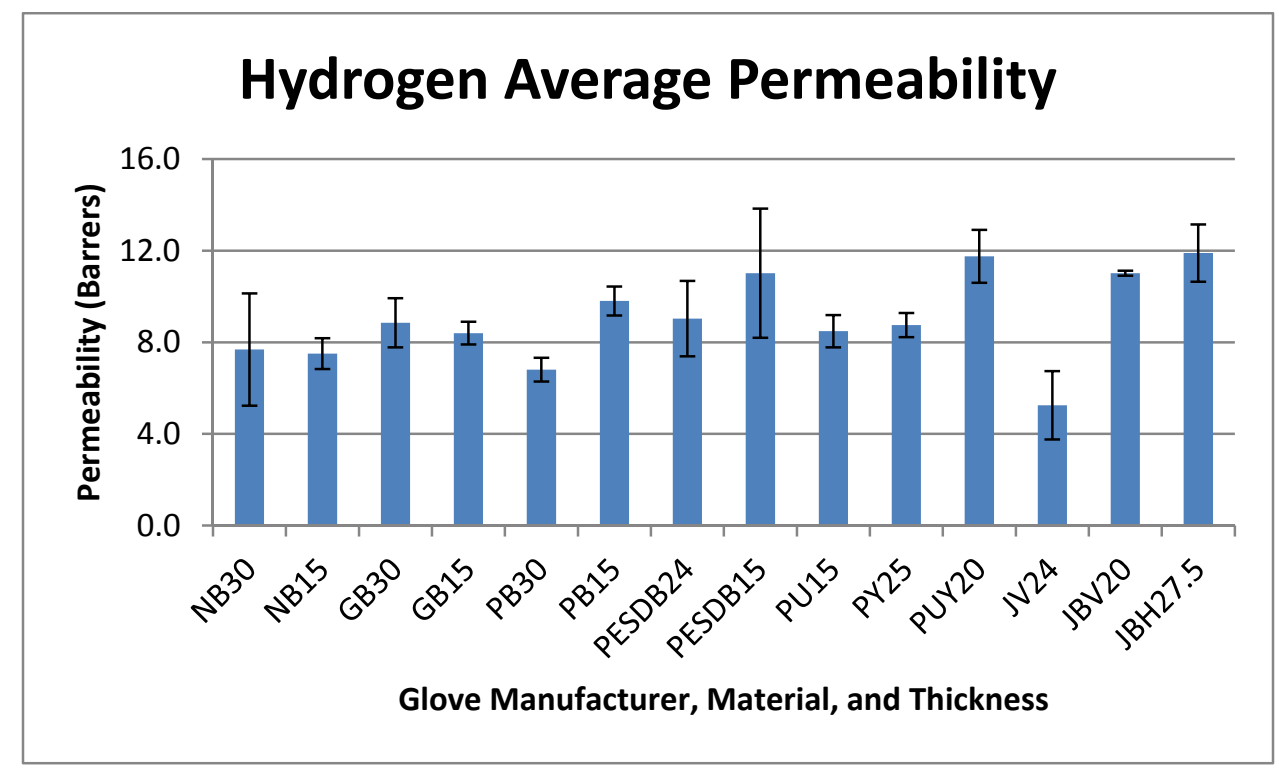

Figure 1. Hydrogen Average Permeability.

\section{Results and Discussion}

The measured permeability of hydrogen and air are indicated in Table 2, Figure 1 and Figure 2. It is apparent from these data that the room temperature permeability of the butyl rubber gloves varies between 7 and 11 barrers $\left(10^{-10}\right) \mathrm{cc}_{2}{ }^{*} \mathrm{~cm} /\left(\mathrm{cm}^{2}{ }^{*} \mathrm{~cm} \mathrm{Hg}\right)$, regardless of glove manufacturer. The data in Figure 1 indicates that the permeability of butyl gloves, regardless of curing treatment, has a similar 
value. A statistical analysis of the hydrogen permeability indicates that all these values are consistent with each other and these determined values for the butyl rubber are consistent with literature data (1).The polyurethane and Hypalon gloves exhibit comparable permeabilities to the butyl gloves with values of 8.5 and 8.7 barrers, respectively. The Jung Viton ${ }^{\circ}$ glove exhibits the lowest hydrogen permeability of the materials tested with a value of about 5 barrers. This permeability value was determined to be statistically significantly lower than the butyl gloves. The composite gloves, i.e., Piercan Polyurethane-Hypalon , Jung Butyl-Hypalon , and Butyl-Viton ${ }^{\circ}$, all exhibit higher permeabilities than the pure compound gloves. The hydrogen permeability varies between 11 and 12 barrers for these compositions.

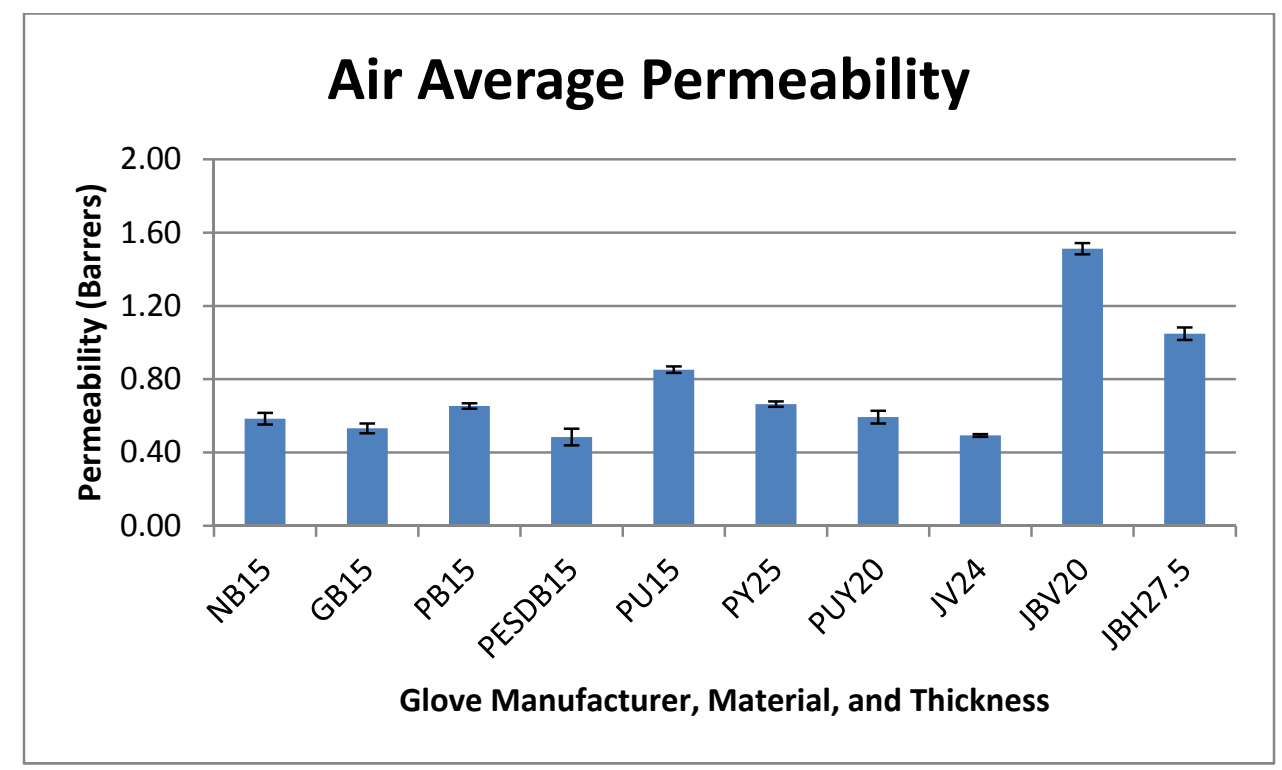

Figure 2. Air Average Permeability

The dry air permeability data, Figure 2 , showed similar trends. The air permeability through each butyl glove varied between $0.48-0.65$ barrers. There is not a significantly lower or higher performing glove from the butyl materials tested. The Viton glove had a dry air permeability of about 0.49 barrers, a value at the lower end of the butyl range. The polyurethane and Hypalon ${ }^{\circledR}$ gloves were at the high end or above the Butyl rubber range, as was the Piercan polyurethane-Hypalon ${ }^{\circledR}$. The Jung Butyl-Viton ${ }^{\circledR}$ and Jung Butyl-Hypalon exhibited air permeabilities about twice the Butyl rubber gloves.

A more practical method to see the effect of the permeability is to examine the amount of tritium expected to permeate through the gloves. A calculation using the following assumptions and constants provides a comparative basis. A glove has a surface area of $3375 \mathrm{~cm}^{2}$, the tritium content is $0.5 \mu \mathrm{Ci} / \mathrm{cm}^{3}$ $\left(2.1 \times 10^{-7} \mathrm{~cm}^{3} \mathrm{~T}_{2} / \mathrm{cm}^{3}\right)$, the internal glovebox pressure is -0.5 in $\mathrm{H}_{2} \mathrm{O}$, the glove descriptions accurately reflect the nominal thickness, e.g., a North $15 \mathrm{mil}$ is nominally $0.015^{\prime \prime}$ thick, and the glovebox and room are at $25^{\circ} \mathrm{C}$. The results of this calculation are shown in Figure 3 for a 24 hour exposure using the 
average permeability for hydrogen that was measured for each glove. The calculations for permeation through each glove indicates that lower permeabilities result in lower overall permeation events and that thicker gloves of the same compound will exhibit lower permeation.

Table 2. Average Hydrogen and Air Permeability.

\begin{tabular}{|c|c|c|c|c|c|c|}
\hline \multicolumn{5}{|c|}{ Average Permeability $10^{-10}$} & \multicolumn{2}{c|}{$\begin{array}{c}\text { Permeability }{ }^{*} 10^{-1} \\
\mathrm{cc} \mathrm{H}_{2}{ }^{*} \mathrm{~cm} /\left(\mathrm{cm}^{2}{ }^{*} \mathrm{~cm} \mathrm{Hg}\right)\end{array} /\left(\mathrm{cm}^{2}{ }^{*}\right.$ atm $)$} \\
\hline ID & $\mathrm{H}_{2}$ & Stdev. & Dry Air & Stdev. & $\mathrm{H}_{2}$ & Air \\
\hline NB30 & 7.7 & 2.5 & NA & NA & 0.58 & NA \\
\hline NB15 & 7.5 & 0.67 & 0.58 & 0.03 & 0.57 & 0.044 \\
\hline GB30 & 8.9 & 1.1 & NA & NA & 0.68 & NA \\
\hline GB15 & 8.4 & 0.50 & 0.53 & 0.03 & 0.64 & 0.040 \\
\hline PB30 & 6.8 & 0.52 & NA & NA & 0.52 & NA \\
\hline PB15 & 9.8 & 0.64 & 0.65 & 0.01 & 0.74 & 0.049 \\
\hline PESDB24 & 9.0 & 1.6 & NA & NA & 0.68 & NA \\
\hline PESDB15 & 11 & 2.8 & 0.48 & 0.05 & 0.84 & 0.036 \\
\hline PU15 & 8.5 & 0.70 & 0.85 & 0.02 & 0.65 & 0.065 \\
\hline PY25 & 8.7 & 0.53 & 0.66 & 0.01 & 0.66 & 0.052 \\
\hline PUY20 & 12 & 1.2 & 0.59 & 0.03 & 0.91 & 0.044 \\
\hline JV24 & 5.2 & 1.5 & 0.49 & 0.01 & 0.39 & 0.037 \\
\hline JBV20 & 11 & 0.11 & 1.5 & 0.03 & 0.84 & 0.11 \\
\hline JBH27.5 & 12 & 1.3 & 1.0 & 0.03 & 0.91 & 0.076 \\
\hline
\end{tabular}

\section{$\mathrm{T}_{2}$ Permeation Through \\ Gloves in $24 \mathrm{hrs}$}

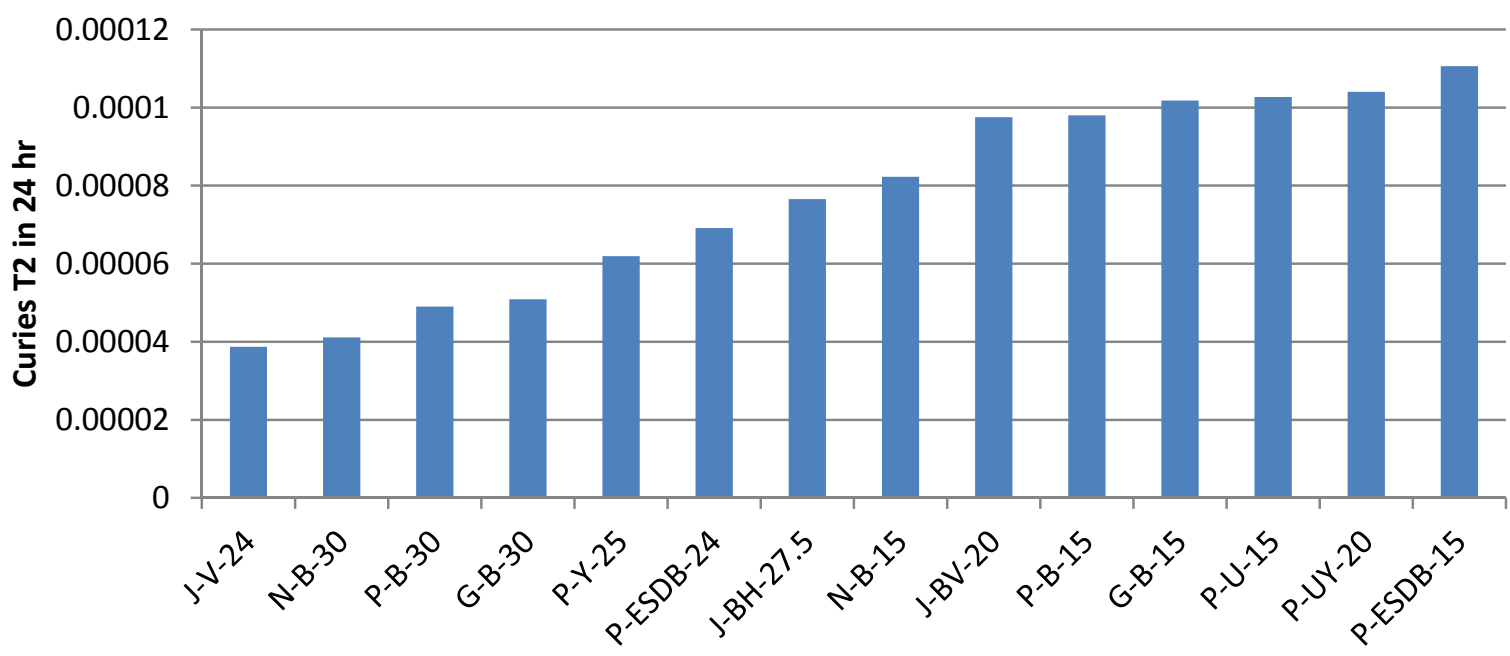

Figure 3. Graphical representation of tritium permeation in $\mathbf{2 4}$ hours for each glove type and thickness tested. 
For the Thermogravimetric Analysis, the specific mass loss for the gloves tested at $90^{\circ} \mathrm{C}$ is presented in Figure 4. The largest mass losses occurred in the following samples Jung $\mathrm{BH} 27.5146^{\circ} \mathrm{C} 12.9 \%$ mass loss, Piercan $\mathrm{Y} 25144^{\circ} \mathrm{C} 11.4 \%$ mass loss, and Jung BV $140^{\circ} \mathrm{C} 5.2 \%$ mass loss, or $3.70 \mathrm{mg} / \mathrm{cm}^{2}, 2,79 \mathrm{mg} / \mathrm{cm}^{2}$, and $1.38 \mathrm{mg} / \mathrm{cm}^{2}$, respectively. The gloves that showed the least amount of off-gassing were the Jung V24 and the Piercan U15. Neither of them exhibited greater than a $0.6 \%$ mass loss. For the butyl gloves Guardian B15 and Piercan B15 showed the least off-gassing, staying below $0.8 \%$ mass loss. The North B15 and the Piercan ESDB15 showed a higher amount of off-gassing from 0.5 to around $3.0 \%$ mass loss. The Piercan production is considering changing over their manufacturing line to this new electrostatic butyl and the amount of off gassing will increase; however, since these ranges fall within the current offgas values of the gloves in the facility (North B15) they may be viable product.

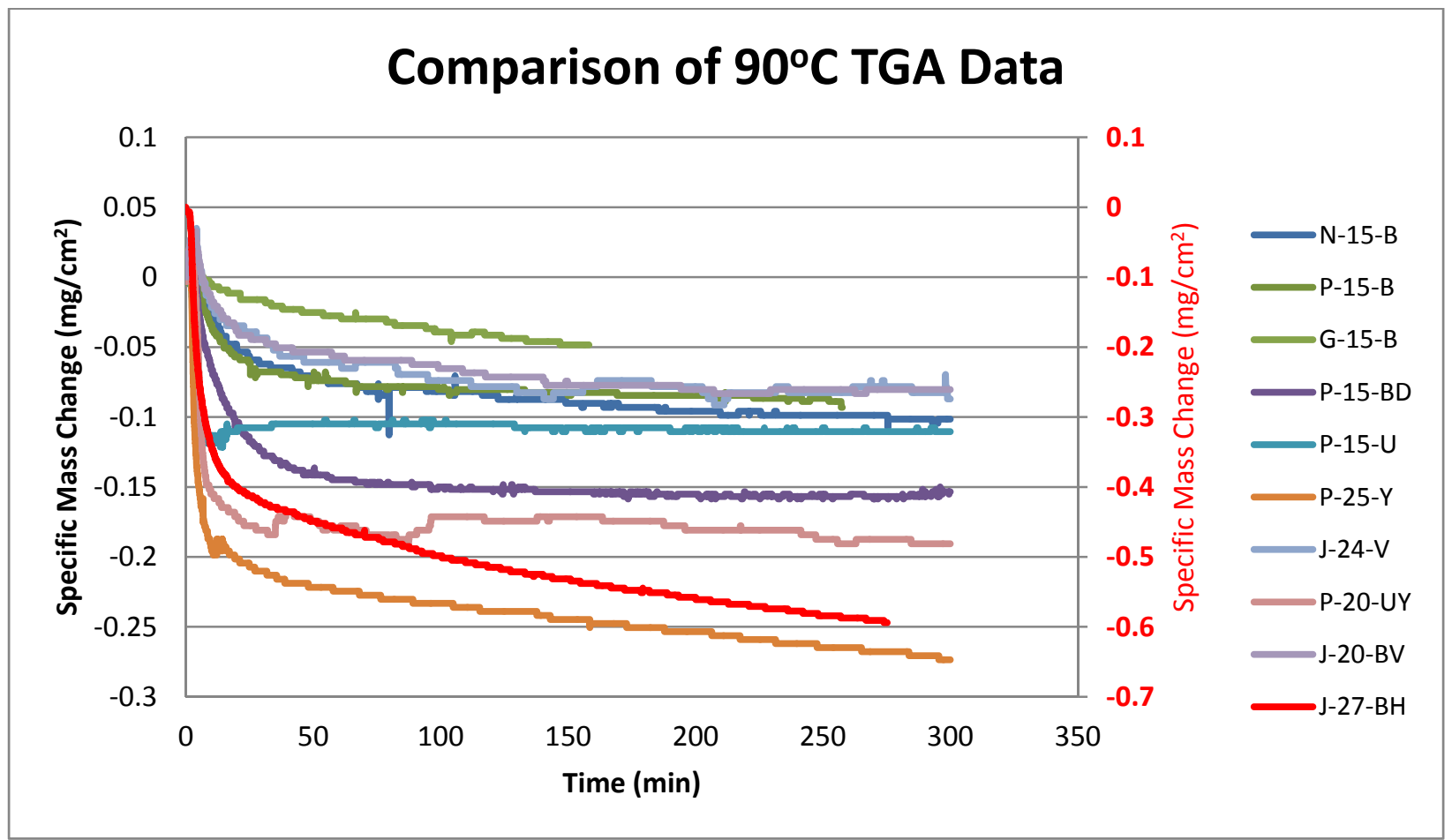

Figure 4. Specific mass change for glove samples exposed at $90^{\circ} \mathrm{C}$ to argon, J-27-BH is read on the right hand axis.

All of the gloves exceed the minimum puncture resistance of $100 \mathrm{lbf} /$ in required for electrical gloves (6). The SRS specification does not explicitly require puncture testing, so these data are for information and comparison purposes only. The gloves can be ranked from highest to lowest puncture resistance: polyurethane, polyurethane-Hypalon ${ }^{\circledR}$, Hypalon , Butyl and Viton ${ }^{\circledR}$, Butyl-Hypalon ${ }^{\circledR}$ and finally ButylViton ${ }^{\circledR}$, as shown in Figure 5. 


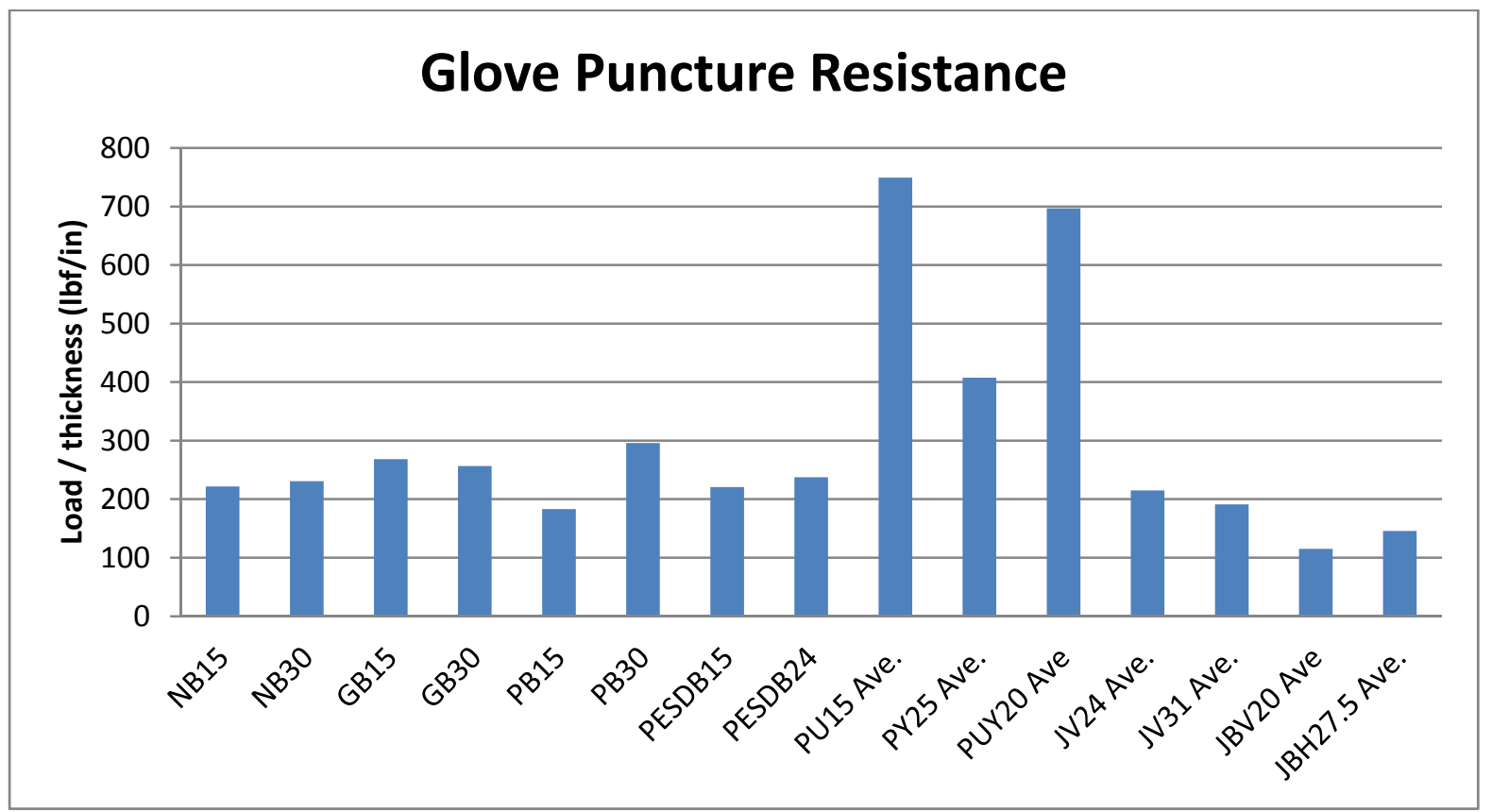

Figure 5. Puncture resistance of the gloves evaluated in this study.

Table 3. Tensile properties of the gloves tested in this study.

\begin{tabular}{|c|c|c|c|c|c|c|c|c|}
\hline & $\begin{array}{l}\text { GB15 } \\
\text { Ave. }\end{array}$ & $\begin{array}{l}\text { GB30 } \\
\text { Ave. }\end{array}$ & $\begin{array}{l}\text { NB15 } \\
\text { Ave. }\end{array}$ & $\begin{array}{l}\text { NB30 } \\
\text { Ave. }\end{array}$ & $\begin{array}{l}\text { PB15 } \\
\text { Ave. }\end{array}$ & $\begin{array}{l}\text { PB30 } \\
\text { Ave. }\end{array}$ & $\begin{array}{c}\text { PESDB15 } \\
\text { Ave. }\end{array}$ & $\begin{array}{c}\text { PESDB24 } \\
\text { Ave. }\end{array}$ \\
\hline $\begin{array}{l}\text { Stress } \\
\text { (Mpa) }\end{array}$ & 11 & 12 & 15 & 13 & 11 & 11 & 13 & 13 \\
\hline$\%$ Elong & 666 & 726 & 745 & 754 & 714 & 843 & 680 & 746 \\
\hline Load (lbf) & 16 & 27 & 23 & 31 & 15 & 27 & 14 & 19 \\
\hline \multirow[t]{2}{*}{$\begin{array}{l}\text { Thickness } \\
\text { (in) }\end{array}$} & 0.020 & 0.029 & 0.021 & 0.034 & 0.019 & 0.032 & 0.015 & 0.020 \\
\hline & $\begin{array}{c}\mathrm{JBH} 27 \\
\text { Ave. }\end{array}$ & $\begin{array}{c}\text { JBV20 } \\
\text { Ave. }\end{array}$ & $\begin{array}{l}\text { JV24 } \\
\text { Ave. }\end{array}$ & JV31 Ave. & $\begin{array}{l}\text { PU15 } \\
\text { Ave. }\end{array}$ & $\begin{array}{c}\text { PUY20 } \\
\text { Ave. }\end{array}$ & PY25 Ave. & \\
\hline $\begin{array}{l}\text { Stress } \\
\text { (MPa) }\end{array}$ & 7.8 & 8.0 & 7.6 & 5.4 & 49 & 24 & 19 & \\
\hline$\%$ Elong & 454 & 640 & 545 & 453 & 697 & 603 & 570 & \\
\hline Load (lbf) & 16 & 10 & 14 & 15 & 55 & 37 & 30 & \\
\hline $\begin{array}{l}\text { Thickness } \\
\text { (in) }\end{array}$ & 0.045 & 0.017 & 0.025 & 0.039 & 0.015 & 0.022 & 0.021 & \\
\hline
\end{tabular}

These tensile strength (TS) results for all the gloves are listed in Table 3. The strength ranges from a low of 5.4 MPa for Viton to a high of $49 \mathrm{MPa}$ for Polyurethane. The rankings are Viton at $5.4 \mathrm{MPA}$ for a 31 mil thick glove as the lowest, the butyl-Hypalon ${ }^{\circ}$, butyl-Viton ${ }^{\circ}$, and 24 mil Viton ${ }^{\circledR}$ are second lowest with about $8 \mathrm{MPa}$, then Butyl at 8-11 MPa, followed by Hypalon at $19 \mathrm{MPa}$, Hypalon -Polyurethane with 24 $\mathrm{MPa}$ and finally, Polyurethane at $49 \mathrm{MPa}$. Graphically these data can be seen in Figure 6 for both tensile 
strength and elongation. All of the samples exhibit at least $400 \%$ elongation with all of the butyl gloves being over $600 \%$.

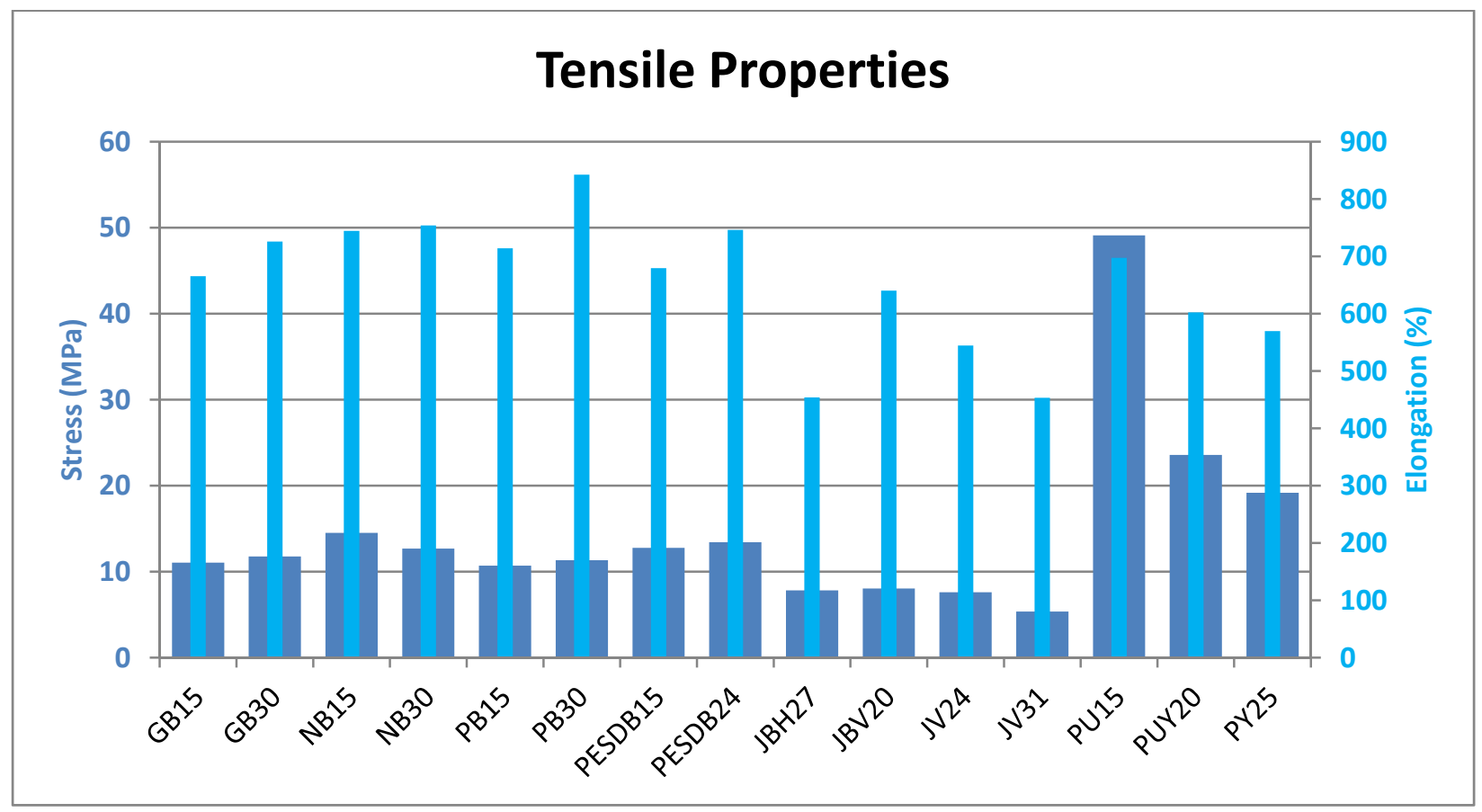

Figure 6. Tensile properties of gloves tested in this study.

Dynamic Mechanical Analysis (DMA) was also conducted on the samples. The materials were generally well behaved with storage moduli and loss moduli decreasing with increasing temperatures, with the exception of North Butyl. North Butyl exhibited an increase in the loss modulus between 50 and $75^{\circ} \mathrm{C}$, the temperature range over which a discontinuity in the permeation as a function of reciprocal temperature was observed. The details are available in Ref. 5 . The glass transition $\left(T_{g}\right)$ temperature for each of the polymers was also determined. The $T_{\mathrm{g}}$, Storage moduli, and $\tan \delta$ are presented in Table 4 . These data indicate that $\mathrm{T}_{\mathrm{g}}$ for Butyl rubber is about $-60^{\circ} \mathrm{C}$; the other gloves have significantly higher $\mathrm{T}_{\mathrm{g}} \mathrm{s}$ at $-30^{\circ} \mathrm{C}$ for polyurethane and approximately $-16^{\circ} \mathrm{C}$ for Hypalon and Viton ${ }^{\circ}$. The composite glove of polyurethane-Hypalon has a $\mathrm{T}_{\mathrm{g}}$ that is intermediate between polyurethane and Hypalon ${ }^{\bullet}$, while Viton ${ }^{\bullet}$ Hypalon ${ }^{\bullet}$ has a more complex $\mathrm{T}_{\mathrm{g}}$ that exhibits a total of three transitions. The additional transition may be due to an interaction between the Viton ${ }^{\circ}$ and Hypalon ${ }^{\circ}$. The glass transition temperatures for gloves with single transitions are presented graphically in Figure 7. All of the $T_{\mathrm{g}} \mathrm{s}$ are well below room temperature, so no adverse effects are predicted for them during operations. 
Table 4. Average measured Tg, Storage Modulus, and Tan $\delta$ for all the samples.

\begin{tabular}{|l|r|r|r|c|}
\hline & $\begin{array}{l}\sim \text { Approx } \\
\mathrm{T}_{\mathrm{g}}\left({ }^{\circ} \mathrm{C}\right)\end{array}$ & $\begin{array}{l}\text { Actual } \\
\mathrm{T}_{\mathrm{g}}\left({ }^{\circ} \mathrm{C}\right)\end{array}$ & $\begin{array}{l}\text { Storage } \\
\text { Modulus at } \\
\mathrm{T}_{\mathrm{g}}(\mathrm{Mpa})\end{array}$ & $\begin{array}{l}\text { Tan } \delta \\
\text { at } \mathrm{T}_{\mathrm{g}}\end{array}$ \\
\hline G15 & -60.8 & -68.6 & 4201 & 0.137 \\
\hline G30 & -60.6 & -68.7 & 4397 & 0.133 \\
\hline N15 & -60.7 & -68.4 & 3795 & 0.140 \\
\hline N30 & -60.2 & -68.1 & 4306 & 0.130 \\
\hline P15 & -60.6 & -68.4 & 2794 & 0.137 \\
\hline P30 & -60.4 & -68.7 & 4288 & 0.132 \\
\hline P15ESDB & -60.6 & -68.4 & 3739 & 0.136 \\
\hline P24ESDB & -59.6 & -69.4 & 3566 & 0.136 \\
\hline P25Y & -16.2 & -25.1 & 1489 & 0.067 \\
\hline P15U & -30.6 & -39.2 & 1852 & 0.068 \\
\hline P20UY & -24.1 & -35.3 & 1935 & 0.055 \\
\hline J24V & -17.0 & -24.5 & 2738 & 0.089 \\
\hline J31V & -16.5 & -24.4 & 2749 & 0.100 \\
\hline
\end{tabular}

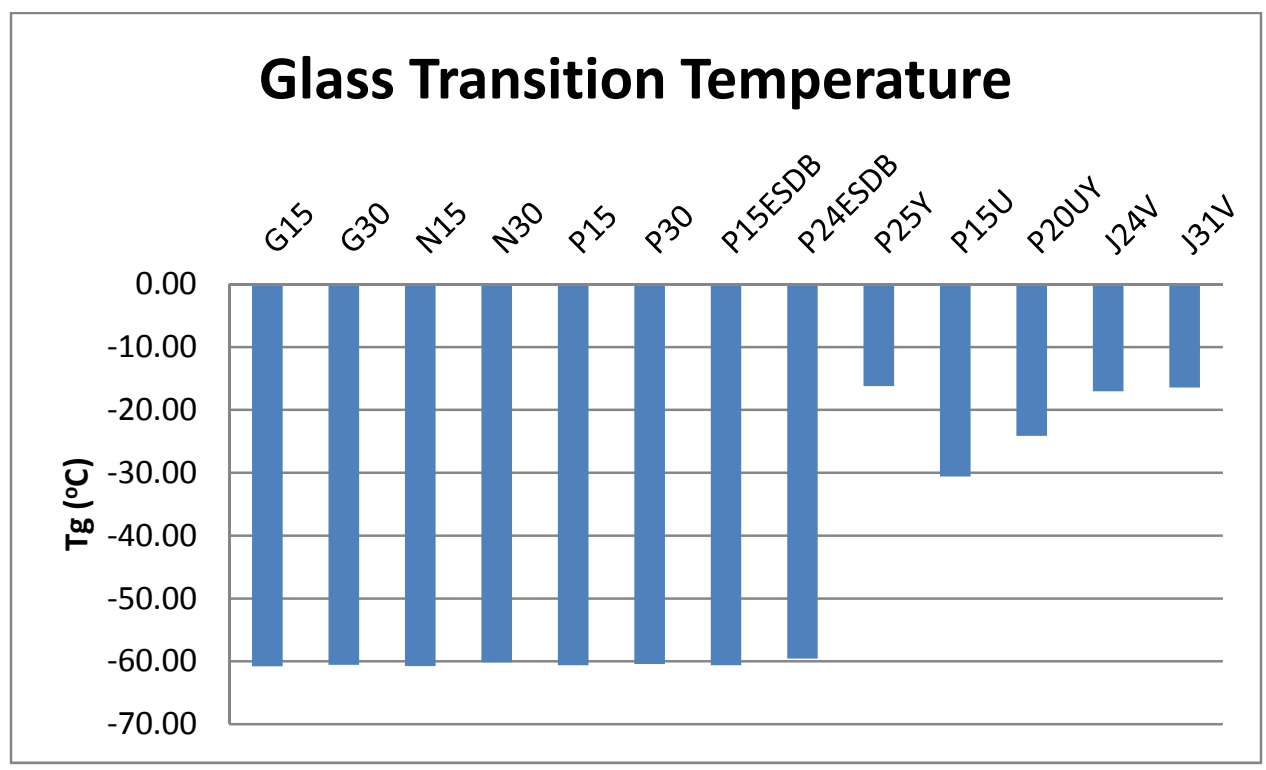

Figure 7. Glass transition temperatures for the gloves tested in this study that exhibited single $\mathrm{T}_{\mathrm{g}}$. 


\section{Summary and Conclusions}

Butyl Rubber samples from gloves supplied have a permeability of between 5 and 11 barrers at room temperature.

The Viton ${ }^{\oplus}$ rubber gloves exhibit the lowest permeability for both air and hydrogen.

Thicker butyl gloves reduce the amount of tritium released from glove boxes.

All of the gloves exhibit some off-gassing of an unknown compound, and additional testing with appropriate analytical test apparatus is recommended.

All of the gloves meet or exceed the $100 \mathrm{lbf} /$ in requirement stated in ASTM D120 for electrical gloves. The Butyl gloves exhibit puncture resistance in excess of $200 \mathrm{lbf} /$ in and the Polyurethane gloves exhibit the highest puncture resistance with a value of nearly $750 \mathrm{lbf} /$ in. Jung Butyl Viton glove failed in a two stage manner with the lowest puncture resistance.

The Piercan Polyurethane gloves were the strongest material tested. They exhibited the highest tensile strength, well over minimum tensile elongation, and the highest load to failure. They were also one of the thinnest gloves tested which may offer improved tactile response.

The glass transition temperature, $T_{g}$, of the materials used in gloves of interest for SRS Tritium Facility glovebox use was determined. The $\mathrm{T}_{\mathrm{g}}$ of all the butyl gloves was consistent and about $-60^{\circ} \mathrm{C}$. The composite gloves exhibited three different behaviors: the Polyurethane-Hypalon ${ }^{\circledR}$ had a $\mathrm{T}_{\mathrm{g}}$ that was intermediate between Polyurethane and Hypalon ${ }^{\circledR}$; the butyl-Viton glove exhibited two distinct $\mathrm{T}_{\mathrm{g}} \mathrm{s}$, at approximately the same values as the component constituents; while the butyl-Hypalon composite material exhibited three distinct $\mathrm{T}_{\mathrm{g}} \mathrm{s}$; one that was at approximately each of the constituent materials and a final one that was about $2^{\circ} \mathrm{C}$.

All of the $T_{g} s$ are well below room temperature and so brittle behavior is not expected for any of the glove materials in Tritium Facility operating conditions. Even the highest measured $\mathrm{T}_{\mathrm{g}}$, of $2^{\circ} \mathrm{C}$ for the Jung Butyl-Hypalon , is well below room temperature.

The North butyl exhibits an increase in the loss modulus at temperatures between 50 and $75^{\circ} \mathrm{C}$. The reason for this increase was not evaluated; however, the temperature range that this deviation was observed in is consistent with the observed change in the plot of log permeation rate as a function of reciprocal temperature.

\section{Acknowledgements}

The authors would like to thank Tritium Operations, Tritium Engineering, and Tritium Extraction Facility for technical and financial support. We would also like to acknowledge Med Allen for facilitating this study and acting as liaison between SRNL / SRS and the glove manufacturers. 


\section{References}

1. SRNL-STI-2012-00028, Evaluation of Glovebox Gloves for Effective Permeation Control, P.S. Korinko, Y. Breakiron, Feb 29, 2012

2. SRNL-STI-2012-00030, Thermogravimetric Characterization of Glovebox Gloves, P.S. Korinko, Y. Breakiron, Feb 29, 2012

3. SRNL-STI-2012-00068, Puncture Test Characterization of Glovebox Gloves, P.S. Korinko, Y. Breakiron, G. K. Chapman, Feb 29, 2012

4. SRNL-STI-2012-00069, Characterization of Tensile Strength of Glovebox Gloves, P.S. Korinko, Y. Breakiron, G. K. Chapman, Feb 29, 2012

5. SRNL-STI-2012-00070, Dynamic Mechanical Analysis Characterization of Glovebox Gloves, P.S. Korinko, Y. Breakiron, Feb 29, 2012

6. ASTM D120-09, Standard Specification for Rubber Insulating Gloves, West Conshohocken, PA 19428, 2009.

7. ASTM D412-06, Standard Test Methods for Vulcanized Rubber and Thermoplastic ElastomersTension, West Conshohocken, PA 19428, 2006. 